\title{
Microsomal Glutathione S-Transferase 2
}

National Cancer Institute

\section{Source}

National Cancer Institute. Microsomal Glutathione S-Transferase 2. NCI Thesaurus.

Code C107112.

Microsomal glutathione S-transferase $2(147 \mathrm{aa}, \sim 17 \mathrm{kDa})$ is encoded by the human MGST 2 gene. This protein plays a role in both the regulation of inflammation and the synthesis of leukotriene C4. 